DOI 10.22363/2313-2310-2018-26-4-461-467

UDC 502.37:504.37

\title{
Case study of fossilized L2 errors correction in ecology students
}

\author{
M.A. Rudneva, N.G. Valeeva \\ Peoples' Friendship University of Russia (RUDN University) \\ 6 Miklukho-Maklaya St., Moscow, 117198, Russian Federation
}

\begin{abstract}
The paper is dedicated to a self-assessment approach as a means of addressing fossilized errors in L2 speaking within the professional communication framework. The phenomenon of fossilization manifests in L2 spoken and written texts on phonological, lexical and grammatical level. Addressing the issue of fossilization has to deal with creating a perfect fluency/accuracy balance, increase of fluency in L2 classroom settings inevitably results in fossilized errors in learners as it compromises their accuracy on a permanent basis. In this respect it is interesting to look into common practices of addressing fossilized errors in advanced L2 classroom. This work is a case study of an attempt to address individual fossilized errors in L2 C1-level students at university level. The paper argues that self-assessment as a means of developing metacognitive awareness and consciousness of advanced L2 learners is a valid tool for eliminating fossilized errors in the long run. We present the results of case study that took place at RUDN University in 2018 within 3 months. During this period a group of advanced L2 learners were asked to record their spontaneous pair interactions, transcribe the conversations and correct their own mistakes. The corrected transcripts were submitted to the L2 instructor for further evaluation and assessment. Small corpora of error-tagged conversations were created for each individual student. Then the instructor created a report on individual mistakes and errors on monthly basis. Persistent, fossilized errors were registered for each individual case and measured at the beginning for the pedagogical experiment and at its end. The paper presents our findings, positive dynamics and overall pedagogical value of establishing correlation between students' previous knowledge and self-assessment.
\end{abstract}

Keywords: self-assessment; English for specific purposes; L2 speaking

\section{Introduction}

Language self-assessment has been an emerging trend in second language assessment due to current shift to learner-centered approach in teaching. Self-assessment itself is considered a controversial issue, as there is no clear definition due to multidimensional nature of assessment itself (appraisal, evaluation, testing, rating) as well as its purposes (placement, diagnostics, evaluation, etc.) [1]. In past research [2-4] self-assessment is generally divided into two main types purpose-wise: 1) performance-oriented; 2) development-oriented. The first type is focused on the performance of L2 learner at

(C) Rudneva M.A., Valeeva N.G., 2018

This work is licensed under a Creative Commons Attribution 4.0 International License 
a particular point of time, the second one addresses the developmental perspective and is aimed at identifying changes over a given period of time. In this paper we focus on development-oriented assessment where the entire process of learning incorporating self-assessment activities is measured. According to Z. Dornyei [5] it overlooks "the participants for an extended period in order to detect changes and patterns of development over time". Current approach to L2 teaching is characterized by an extensive degree of learner autonomy and self-regulation, with the focus being shifted from the teacher to the learner. L2 learners are expected to be active participants of evaluation and assessment $[2 ; 6]$ with the entire assessment process seizing to be teacher's sole responsibility [4]. According to past research, introduction of self-assessment leads to a number of positive outcomes, i.e. enhancing autonomy and productivity, decrease of frustration, increase of motivation and engagement, improvement of retention rate [4;6;7-12]. Among the shortcomings of self-assessment one can mention numerous inputs into L2 learners' speech production in a developmental perspective, i.e. the feedback of peers, teachers and parents can affect the validity of the overall result of graded production. However, the research mentioned above also acknowledge enhancement of students' language learning by self-assessment, due to increase of learner autonomy. Of specific interest is implementation of self-assessment techniques to error analysis.

Error analysis was suggested as a new approach to interlanguage [13], i.e. a system which contains L1 as well as L2 features. Considering learners' interlanguage from a developmental perspective fosters understanding of learning processes [14]. Based on the nature or errors they can be divided into developmental ones (gradually developed throughout the process of learning) or fossilized ones (stable and permanent) [15]. Fossilization is known as "the long-term persistence of the non-target-like structures in the interlanguage of non-native speakers" [16]. Fossilization is defined as an inability for further language growth despite positive factors, such as motivation, practice and exposure to authentic input. This paper focuses on a case study aimed at detecting and targeting fossilized errors in the spoken production of advanced L2 learners. The paper argues that self-assessment is a valid approach of treating fossilized errors at upper levels of language proficiency.

\section{Methodology}

The participants of this study were selected on voluntary basis from the same ESP class, 2nd year students majoring in environmental studies. There were 4 participants, 2 male and 2 female, aged 19-20 with L1 Russian. The group was initially formed on the basis of the scores of entry streaming test. The Oxford placement test was used for streaming, it consisted of listening and grammar sections, 100 questions, 1 hour to complete. The students were grouped according to the results of the test, the entire group demonstrated around $\mathrm{C} 1$ proficiency level.

The corpus of data for this study was the transcripts of independent speech production of the participants during ESP classes. Data was collected for 3 months during the first semester of 2018. Once a week the students were asked to present a spontaneous dialogue based on the topic discussed in the current class. They had time to prepare their interaction before presenting it to the instructor, however, they were specifically requested not to 
write anything down or read during the presentation. Each dialogue was audio-recorded, transcribed and checked for errors. First month of the pedagogical experiment transcription and error-assessment were done by the instructor. We were looking into grammatical, lexical and pronunciational errors. After identifying errors, we specifically looked into those which demonstrated persistence across individual speech production (fossilized ones). To identify those one-way ANOVAs as well as Tukey Post Hoc analyses were performed for each error, then we identified the mean differences. In case if there was no statistically significant difference of a specific error in individual speech production, we considered it fossilized and targeted on the next level of our practices.

For each student top 10 fossilized errors were defined and indicated, in each case those were specific ones, which could not be addressed as a part of group work. For two consecutive months the participants were asked to transcribe their dialogues and detect errors in their own speech production. The results were submitted to the instructor and discussed on the weekly basis.

\section{Results}

The fossilized errors were categorized in grammatical, lexical and pronunciational ones. We picked top 10 errors for each participant, based on the frequency. Table 1 presents distribution of errors for each participant, females (F1 and F2) and males (M1 and M2).

Table 1

Error types

\begin{tabular}{|c|c|c|c|}
\hline & Grammatical & Lexical & Pronunciational \\
\hline F1 & $2(20 \%)$ & $1(10 \%)$ & $7(70 \%)$ \\
\hline F2 & $3(30 \%)$ & 0 & $7(70 \%)$ \\
\hline M1 & $4(40 \%)$ & $2(20 \%)$ & $4(40 \%)$ \\
\hline M2 & $2(20 \%)$ & $3(30 \%)$ & $5(50 \%)$ \\
\hline
\end{tabular}

As we can see from Table 1, the most frequent fossilized errors in advanced L2 learners are pronunciational ones. This can be put down to a fact that listening is the skill traditionally overlooked at Russian schools, very little to none attention is paid to pronunciation development as well. Therefore, students acquire non-native-type pronunciation, besides, certain words are mispronounced. This has to be addressed at tertiary level.

For this particular paper we picked 2 pronunciational errors that were characteristic of the majority of participants: 1) although being commonly pronounced as [' $0: 1 \mathrm{~s} ə 0$ ] and 2) since being commonly pronounced as ['saiəns].

Table 2 presents distribution of mispronounced word although among 3 participants of the study throughout 8 weeks of the experimental self-assessment.

Table 2

Frequencies for although

\begin{tabular}{|c|l|l|l|l|l|l|l|l|}
\hline Weeks & 1 & 2 & 3 & 4 & 5 & 6 & 7 & 8 \\
\hline F1 & 4 & 3 & 3 & 2 & 1 & 1 & 0 & 0 \\
\hline F2 & 3 & 3 & 2 & 2 & 2 & 1 & 1 & 1 \\
\hline M1 & 3 & 3 & 1 & 1 & 1 & 0 & 0 & 0 \\
\hline
\end{tabular}


According to our findings 3 of 4 participants consistently mispronounced the word although. Table 2 presents absolute frequencies of error occurrence per speech unit on a weekly basis. Participant F1 demonstrates steady decrease of the misuse, she started with the highest number of error occurrence among the group, however, in weeks 7 and 8 she did not demonstrate the mispronounced item. Participant F2 demonstrated a decrease in mispronunciation, however, the fossilized error still occurs in her speech and requires more attention. It should be noted her though, that the cases of on-the-spot self-corrections were not indicated here, so single occurrences of the error in past few weeks were compensated for by self-correction. Participant M1 demonstrated the best progress among all 3, already in week 3 he limited mispronunciation to a single occurrence, in weeks 6 to 8 he demonstrated correct pronunciation.

Table 3 presents distribution of mispronounced word since among 2 participants of the study throughout 8 weeks of self-assessment experiment.

Table 3

Frequencies for since

\begin{tabular}{|c|l|l|l|l|l|l|l|l|}
\hline Weeks & 1 & 2 & 3 & 4 & 5 & 6 & 7 & 8 \\
\hline F2 & 2 & 2 & 1 & 1 & 2 & 1 & 0 & 0 \\
\hline M2 & 3 & 2 & 2 & 2 & 1 & 0 & 0 & 0 \\
\hline
\end{tabular}

The results of the study confirmed that 2 out of 4 participants consistently mispronounced the word since. Table 3 presents absolute frequencies of error occurrence per speech unit on a weekly basis. Participant F2 demonstrates resistance in preserving the error, up to week 6 she keeps mispronouncing the word, although it is on the list of 10 individual errors that she was requested to look after. However, in weeks 7 and 8 she managed to reduce the mispronunciation to 0 . Participant $\mathrm{M} 2$ started off with the biggest number of error occurrences, however, through weeks 2 to 5 he demonstrated steady decrease of item misuse and in weeks 6 to 8 - correct pronunciation.

\section{Conclusions}

Encouraged by the previous studies that emphasized the ambiguous nature of selfassessment, this study focused on the validity of self-assessment as an approach to address fossilized errors. The transcripts of the students' speech production provide a good evidence that even at advanced levels learners make a few errors, which are resistant and hinder further progress. Because of this, it felt necessary to diagnose these errors, identify the most common ones and propose reparative mechanisms to tackle them.

The findings of this study call for further research in this area. Primarily, we have to look into grammatical and lexical fossilized errors and work out the ways to address those. Here self-correction can only be a part of reparative strategy, an instructor has to propose various guided practice exercises, such as fill-in-the-blank, multiple choice questions, translation from L1 to L2 and vice versa. Secondly, due to complex, metacognitive nature of self-correction, more research is needed to understand outcomes or its implication, whether certain degree of learner autonomy can be beneficial for L2 learners, what role motivation and engagement factors play. Finally, the present research calls for longitudinal case studies of treating fossilized errors in advanced students to come up with the best solution of this important problem. 


\section{References}

[1] Henning G. A guide to language testing: development, evaluation, research. Rowley, MA: Newbury House; 1987.

[2] Bachman LF. Learner-directed assessment in ESL. In: Ekbatani G, Pierson H (eds.). Learnerdirected assessment in ESL. New Jersey: Lawrence Erlbaum Associates, Inc.; 2000: ix-xii.

[3] Haughton G, Dickinson L. Collaborative assessment by masters' candidates in a tutor based system. Language Testing. 1988;5: 233-246.

[4] Oscarson M. Self-assessment of language proficiency: rationale and applications. Language Testing. 1989;6(1): 1-13.

[5] Dornyei Z. Teaching and researching motivation. London: Pearson Education Ltd.; 2001.

[6] Dickinson L. Self-instruction in language learning. London: Cambridge University Press; 1987.

[7] Ellis R. The study of second language acquisition. Oxford: Oxford University Press; 1994.

[8] Gardner RC, MacIntyre P. Motivational variables in second language acquisition. Studies in Second Language Acquisition. 1991;13: 57-72.

[9] McNamara M, Deane D. Self-assessment activities toward autonomy in language learning. TESOL Journal. 1995;5: 18-23.

[10] O’Malley JM, Pierce LV. Authentic assessment for English language learners. Boston, MA: AddisonWesley Publishing Company; 1996.

[11] Peirce BM, Swain M, Hart D. Self-assessment, French immersion, and locus of control. Applied Linguistics. 1993;14: 25-42.

[12] Rivers WP. Autonomy at all costs: an ethnography of metacognitive self-assessment and selfmanagement among experienced language learners. The Modern Language Journal. 2001;85: 279-290.

[13] Selinker L. Interlanguage. International Review of Applied Linguistics in Language Teaching (IRAL). 1972;10(1-4): 209-232.

[14] Ellis R. Understanding second language acquisition. Vol. 31. Oxford University Press; 1989.

[15] Richards JC. Error analysis: perspective on second language acquisition. London, UK: Longman; 1974.

[16] Selinker L, Lakshmanan U. Language transfer and fossilization: the multiple effects principle. In: Gass S, Selinker L (eds.). Language transfer in language learning. Amsterdam: John Benjamins; 1992: 197-216.

\section{Article history:}

Received: 22.12.2018

Revised: 10.01 .2019

\section{For citation:}

Rudneva MA, Valeeva NG. Case study of fossilized L2 errors correction in ecology students. RUDN Journal of Ecology and Life Safety. 2018;26(4): 461-467. DOI 10.22363/2313-2310-201826-4-461-467

\section{Bio Note:}

Maria A. Rudneva - Candidate of Philology, Associate Professor of the Department of Foreign Languages of the Environmental Faculty of the Peoples' Friendship University of Russia (RUDN University).Contact information: e-mail: rudneva_ma@rudn.university

Nailya G. Valeeva - Candidate of Pedagogical Sciences, Professor, Head of the Department of Foreign Languages of the Peoples' Friendship University of Russia (RUDN University) Ecological Faculty. Contact information: e-mail: valeeva_ng@rudn.university 


\title{
Коррекция фоссилизации на примере студентов-экологов
}

\author{
М.А. Руднева, Н.Г. Валеева \\ Российский университет дружбы народов \\ Российская Федерация, 117198, Москва, ул. Миклухо-Маклая, 6
}

В статье рассматривается самопроверка как способ коррекции лексической и грамматической фоссилизации в устной речи студентов-экологов, изучающих английский язык. Фоссилизация проявляется на фонологическом, лексическом и грамматическом уровнях. Проблема возникает в рамках достижения оптимального баланса беглости и безошибочности речи, когда при росте скорости речепорождения неизбежно возникают устойчивые (фоссилизированные) ошибки. В этой связи представляет интерес исследование работы по устранению такого рода ошибок из иноязычной речи студентов продвинутого уровня. В статье описывается подход к устранению фоссилизированных ошибок в иноязычной речи студентов университета, в основу которого легло предположение, что самопроверка является эффективным инструментом для устранения подобных ошибок. Представлены результаты педагогического эксперимента, проведенного на экологическом факультете Российского университета дружбы народов в течение трех месяцев 2018 года. В ходе эксперимента были созданы индивидуальные корпусы спонтанных диалогов для каждого участника эксперимента, затем выявлены типичные устойчивые ошибки, и студентам было предложено исправить их самостоятельно. Результаты внедрения описанного подхода показали положительную динамику в устранении устойчивых ошибок.

Ключевые слова: самопроверка; английский язык для специальных целей; иноязычная речь

\section{Список литературы}

[1] Хеннинг Г. Руководство по языковому тестированию: разработка, оценка, исследование. Роули, Массачусетс: Ньюбери Хаус, 1987.

[2] Bachman L.F. Learner-directed assessment in ESL // Learner-directed assessment in ESL / G. Ekbatani, H. Pierson (eds.). New Jersey: Lawrence Erlbaum Associates, Inc., 2000. Pp. IXXII.

[3] Хотон Г., Дикинсон Л. Совместная оценка поступающих в магистратуру в системе Tutor // Языковое тестирование. 1988. Т. 5. С. 233-246.

[4] Оскарсон М. Самопроверка владения языком: обоснование и применение // Языковое тестирование. 1989. Т. 6. № 1. С. 1-13.

[5] Дорней 3. Учебно-исследовательская мотивация. Лондон: Pearson Education Ltd, 2001.

[6] Дикинсон Л. Самообучение в изучении языка. Лондон: Издательство Кембриджского университета, 1987.

[7] Эллис Р. Изучение овладения вторым языком. Оксфорд: Издательство Оксфордского университета, 1994.

[8] Gardner R.C., MacIntyre P. Motivational variables in second language acquisition // Studies in Second Language Acquisition. 1991. Vol. 13. Pp. 57-72.

[9] Макнамара М., Дин Д. Роль самопроверки в автономном изучении иностранного языка // TESOL Journal. 1995. T. 5. C. 18-23.

[10] О'Мэлли Дж. М., Пирс Л.В. Аутентичные оценки для изучающих английский язык. Бостон, Массачусетс: Эддисон-Уэсли, 1996.

[11] Пирс В.М., Суэйн М., Харт Д. Самооценка, погружение в французский язык и локус контроля // Прикладная лингвистика. 1993. Т. 14. С. 25-42. 
[12] Реки У.П. Автономия любой ценой: этнография метакогнитивной самооценки и самоуправления среди продвинутых изучающих язык // The Modern Language Journal. 2001. T. 85. C. 279-290.

[13] Селинкер Л. Интерлингвист // Международный обзор прикладной лингвистики в преподавании языков (IRAL). 1972. Т. 10. № 1-4. C. 209-232.

[14] Эллис Р. Понимание освоения второго языка. Т. 31. Оксфорд: Издательство Оксфордского университета, 1989.

[15] Ричардс Дж.С. Анализ ошибок: перспектива овладения вторым языком. Лондон: Longman, 1974.

[16] Selinker L., Lakshmanan U. Language transfer and fossilization: the multiple effects principle // Language transfer in language learning / S. Gass, L. Selinker (eds.). Amsterdam: John Benjamins, 1992. Pp. 197-216.

\section{История статьи:}

Дата поступления в редакцию: 22.12.2018

Дата принятия к печати: 10.01.2019

\section{Для цитирования:}

Rudneva M.A., Valeeva N.G. Case study of fossilized L2 errors correction in ecology students (Коррекция фоссилизации на примере студентов-экологов) // Вестник Российского университета дружбы народов. Серия: Экология и безопасность жизнедеятельности. 2018. T. 26. № 4. C. 461-467. DOI 10.22363/2313-2310-2018-26-4-461-467

\section{Сведения об авторах:}

Руднева Мария Андреевна - кандидат филологических наук, доцент кафедры иностранных языков экологического факультета Российского университета дружбы народов. Контактная информация: e-mail: rudneva_ma@rudn.university

Валеева Наиля Гарифовна - кандидат педагогических наук, профессор, заведующая кафедрой иностранных языков экологического факультета Российского университета дружбы народов. Контактная информация: e-mail: valeeva_ng@rudn.university 